Debreceni Jogi Múhely 2021. (XVIII.) 3-4.

Debreceni Egyetem, Állam- és Jogtudományi Kar, Debrecen

(University of Debrecen, Faculty of Law, Debrecen)

DOI 10.24169/DJM/2021/3-4/2

\title{
Elena-Ana Iancu
}

full professor and dean

Agora University of Oradea Municipality

Faculty of Legal and Administrative Sciences

Enache Tuşa

lecturer

"Ovidius" University of Constanța

Faculty of Psychology and Educational Sciences

\section{CRIMINAL OFFENCES THAT INFRINGE ON INDIVIDUAL FREEDOM VERSUS RESTRICTIONS IMPOSED DURING THE PANDEMIC TO GUARANTEE ACCESS TO EDUCATION}

Debreceni Jogi Műhely, 2021. évi (XVIII. évfolyam) 3-4. szám (2022. február 15.)

DOI $10.24169 / \mathrm{DJM} / 2021 / 3-4 / 2$

\begin{abstract}
In the study we propose as follows, we will look at differences in perception between the pandemic constraints imposed by the governmenst of countries affected by the pandemic in view of managing the pandemic and society's perception that governments have deprived citizens of their freedom by restricting their mobility and imposing restrictions with regard to travel, including in order to attend educational activities. In some cases, the communities affected by the restrictive measures have gone further, accusing governments of the crime of "Illegal Deprivation of Freedom", which is included by the legislator in the criminal codes of countries. We consider that the accusations brought against the authorities are unfounded, exaggerated, and thoroughly wrong. We believe that they are due to communication gaps in the public domain, the differences in perception of community members in the context of changing paradigms and the insufficient legal education, which leads to confusion between illegal deprivation of freedom and limitations or restrictions. Although, in the legislation, the articles that provide for the criminal offences relevant to the matter are included in the criminal (penal) codes, for example, in the Romanian legislation in Article 205 of the Criminal Code, with the marginal name "Offences against Individual Freedom" of Title I, which bears the marginal name "Offences against the Person", and falls within the area of interest of legal sciences, we will analyze the effects in relation to the limitations and restrictions imposed by the authorities for the management of the pandemic. To this end, on the one hand we will highlight the aspects of material criminal law necessary for the legal classification of a deed as offence of illegal deprivation of freedom, in accordance with the provisions of the Criminal Codes of Romania, Hungary, Republic of Italy, Greece, and on the other hand, we will present some aspects regarding the management of the coronavirus crisis in the area of education.
\end{abstract}

Keywords: freedom, criminal offence, limitations, communication, Covid 19 pandemic

Absztrakt: A tanulmányban megvizsgáljuk a világjárvánnyal sújtott országok kormányai által a világjárvány kezelése során érvényesített, pandémiával összefüggő korlátozások és a társadalom azon felfogása közötti különbségeket, amelyek szerint a kormányok - mobilitásuk korlátozásával - megfosztották az egyéneket szabadságuktól, beleértve az utazással kapcsolatban - az oktatásban való részvétel lehetôségére is kihatóan - bevezetett korlátozásokat is. Egyes esetekben a korlátozó intézkedések által érintett közösségek tovább mentek, és a kormányokat „,személyi szabadság megsértése” bűncselekményével vádolják, amely az egyes országok büntető törvénykönyveiben is megtalálható deliktum. A hatóságokkal szemben felhozott vádakat megalapozatlannak, eltúlzottnak és teljesen hibásnak tartjuk. Úgy gondoljuk, hogy ezek a társadalmi kommunikáció hiányosságaiból, a közösség tagjainak - változó paradigmákból eredő - felfogásbeli 
Debreceni Jogi Múhely 2021. (XVIII.) 3-4.

Debreceni Egyetem, Állam- és Jogtudományi Kar, Debrecen

(University of Debrecen, Faculty of Law, Debrecen)

DOI 10.24169/DJM/2021/3-4/2

különbségeiből és az elégtelen jogi képzettségből adódnak; ezek alapján egyesek összetévesztik a személyi szabadság megsértésének bủncselekményét a korlátozások érvényesítésével. Habár a jogrendszerben a kérdéssel kapcsolatos búncselekményekről rendelkező szabályok a büntetô törvénykönyvekben szerepelnek - ilyen például a román jogban a Btk. 205. cikkelye az „Egyéni szabadság elleni búncselekmények” név alatt, amely a „Személy elleni bűncselekmények” nevet viselő I. Címben található, s a jogtudományok érdeklődési körébe tartozik -, elemezzük a hatóságok által a járvány kezelése során érvényesített korlátozások hatásait is. Ennek érdekében egyrészt kiemeljük azokat az anyagi büntetőjogi szempontokat, amelyek szükségesek egy cselekmény személyi szabadság megsértése bủncselekményének minősítéséhez a román, a magyar, az olasz és a görög büntető törvénykönyv rendelkezései szerint, másrészt bemutatunk néhány, a koronavírusválság - oktatást érintő - kezelésével kapcsolatos szempontot.

Kulcsszavak: szabadság, bủncselekmény, korlátozások, kommunikáció, Covid 19 világjárvány

\section{Introduction}

The current pandemic context has caused significant disturbances in activities in the public sphere, in the public domain, but also among players in the educational process (teaching staff, students (pupils), auxiliary teaching staff). The limitations imposed by the governments have aggravated existing social inequalities and have made it necessary to adopt new methods of communication among public institutions, society and the educational system. In the current context of the pandemic, restrictions with various degrees of limitation are imposed, and this has caused dissatisfaction among significant segments of society that responded by criticizing governments for drastically restricting their freedoms. Another aspect of freedom restriction has also been brought into question, namely the limitation of students' access to the educational system, which was forced to relocate in the online environment. Teachers, students, additional materials, homework, school guidance and discussions found new ways of expression, while applications mainly intended for communication were turned into work tools. In the new context generated, which has brought about significant changes in terms of the organization of educational logistics in schools and classrooms, of timetables and the actual manner of carrying out teaching activities, getting to know the children and their family environment, with their specific traits, has become an issue of great interest.

Communication in the public domain must be studied as a process in which members of society take part, regardless of the social segment they belong to. This participation develops the capacity to improve the learning experience and to generate a meaningful understanding of the realities that lead to the imposition of restrictive measures. Effective communication is a process of exchange of ideas, thoughts, knowledge and information in a manner that allows fulfilling the purpose or intention in the most effective way possible. In other words, it is no more and no less than the expression of opinions by the sender in a way that the recipient understands best. Thus, communication that was not adjusted to the categories of recipients caused confusion in understanding the message, which confirmed various perceptions and sparked protests across society. The crisis caused by the coronavirus has had adverse effects on the educational process, which was interrupted for a significant period of time, as an absolutely necessary and effective measure adopted by the central authorities in order to protect students from infection with the new virus.

The closing down of schools disturbed not only the children's educational process, but also their access to the food provided by schools, welfare support and referral to basic medical and social services. The challenge awaiting teachers, head teachers, leaders of the educational system and local and national decision-makers, is a major one (Antonowicz, et al., 2020, p. 4). In this context, on 12 $12^{\text {th }}$ March 2020, school classes were suspended, and on 16 th March, 2020, Presidential Decree No. 195 established a state of emergency on the Romanian territory, which was extended until $15^{\text {th }}$ May 2020, when the state of emergency was abolished, being replaced by a state of alert that is still in force at present (January 2022).

During this period, in the public domain, a part of society expressed/circulated the idea of violation of citizens' rights and freedoms, and another part thereof upheld that the restrictions are well-founded, given the pandemic context, the need to ensure public health safety within communities and to prepare institutional resilience. 
Debreceni Jogi Múhely 2021. (XVIII.) 3-4.

Debreceni Egyetem, Állam- és Jogtudományi Kar, Debrecen

(University of Debrecen, Faculty of Law, Debrecen)

DOI 10.24169/DJM/2021/3-4/2

The Romanian Constitution contains guarantees for the respect of fundamental human rights and freedoms, but also provides for measures the governmental authorities can implement in order to limit the effects of a pandemic and to ensure public health.

In the same vein, we can assert that the protection of rights through the criminalization of deeds that infringe on fundamental values enshrined in the Romanian Constitution provides a climate of safety for human beings, contributes to increasing security and positively influences the perspective people have on the restrictions imposed in the pandemic context. In this respect, we refer to Title II bearing the marginal name "Fundamental Rights, Freedoms and Duties", which, in Article 23, provides that individual freedom is inviolable. In cases where the social values related to such freedom are infringed upon, the deeds are classified as criminal offences, if they cumulatively meet the main features of a criminal offence, as defined by the Criminal Code of Romania (CC), Art. 15.

In Romania, specific measures were adopted in the general pandemic context by virtue of the Decree of the President of Romania No. 195 of $16^{\text {th }}$ March 2020 establishing the state of emergency on the territory of Romania (published in the Official Journal Part I, issue no. 311 of 14th April 2020), of the decrees extending the state of emergency on the territory of Romania. Other regulations were the government decisions establishing and extending the state of alert, as well as the decisions of the National Committee for Emergency Situations and the County Committees for Emergency Situations and Law no. 55/2020 regarding some measures for preventing and combating the effects of the COVID-19 pandemic (published in the Official Journal no. 396 of $15^{\text {th }}$ May 2020).

In the context of this pandemic, it becomes mandatory to be aware of regulations governing exceptional circumstances, and the pandemic which started in 2020 imposed the implementation of this restrictive regime. Misunderstandings occurred as a result of the lack of additional details aimed at informing society about the differences between medical restrictions and the illegal deprivation of freedom, as provided for in the Criminal Code. Effective communication achieves the desired effect and will support the process with the potential to improve the effect of the message. Therefore, the message transmitted through communication serves the purpose for which it was intended or designed. Possible objectives would be to produce change, encourage action, create awareness, educate or convey an idea or perspective. Good communication involves being able to speak, as well as to listen (Velentzas and Borni, 2014).

Human rights, individual life and freedom have been subject to research over the course of time, being a constant concern for specialists in various fields, such as: legal sciences, philosophy, political sciences, sociology, psychology, and were especially reflected and debated on, nuanced in the public domain at times of changes in paradigm in relation to the evolution of humankind or when events of the "black swan" type touched the human race (Taleb, 2010, p. 16).

Individual freedom asserts itself as a fundamental right of human beings, as a major component of the human condition, as an imperative dictated by the contemporary society's need for progress. It is not a concept invented by jurists, nor a treasure trove of philosophers, but results from an objective relationship. People are the ones who choose and decide on their goals, pathways of action, but not regardless of the conditions in which they live (Istrate, 1984, p. 3). As a social value, the right to freedom is important both for an individual and for society because, if a person is free, the process of his/her self-assertion in society will have positive consequences on the sustainable development of that society (Dongoroz, 1969, p. 63).

The promotion of a feeling of safety within the community / society will render co-habitation more pleasant and stable. Therefore, effective communication should be a priority, not a forgotten thought for the representatives of institutions (Hilliard and Newsome, 2013, pp. 353-364). Effective communication occurs when a desired effect is the intended result or an unintended exchange of information happens, that is comunicated by various emitters and transmitted in the desired manner. This study also responds to accusations from certain segments of society, claiming that the rights of students have been violated and that they have been deprived of educational services throughout the duration of the coronavirus pandemic.

At the same time, the study aims to propose the idea that online learning has an effect on communication between teachers and students, by making it more effective and easy. Online education has forced the 
Debreceni Jogi Múhely 2021. (XVIII.) 3-4.

Debreceni Egyetem, Állam- és Jogtudományi Kar, Debrecen

(University of Debrecen, Faculty of Law, Debrecen)

DOI 10.24169/DJM/2021/3-4/2

academic environment to open more widely towards the process of digitization during the Covid-19 pandemic, which has an impact on the students' level of efficiency. Effective communication between teachers and students during online courses can also be assessed and methods for improving it can be suggested.

Deprivation of freedom has been explained in the specialized literature (Vasili et al., 1975, p. 165) ${ }^{1}$, but while the material element is concretely achieved by confining a person to a room, the passive subject can move within a limited space but cannot reach the place he initially intended to go to. As a result, he will be subjectively affected, too. The criminal law does not provide for a time limit, there is no other essential requirement related to the material element of the objective side, namely to the action and or inaction by which the deprivation of freedom is carried out illegally, but for it to be illegal. In practice, there may be situations in which, although there is an intention to commit another criminal offence, the deprivation of freedom exceeds the time required to commit the complex offence (e.g., the criminal offence of rape, the criminal offence of robbery), in which case a concurrence of offences will be retained.

1. Aspects of comparative law regarding criminal offences that infringe upon individual freedom and the limitation of rights.

We will present as follows a description of regulations in criminal matters with regard to the offence of illegal deprivation of freedom. We take into consideration the criminal codes in force in: Romania, Hungary, Italy and Greece, all these countries being Member States of the European Union. On another note, these countries found themselves forced to take action for the management of the coronavirus pandemic, by restricting movement in the public domain, by activating certain institutional control and monitoring mechanisms. We will present the main provisions of the criminal codes in order to compare them with the measures of restriction and limitation of some public activities or services.

\subsection{Regulation in the Criminal Code of Romania}

In Title I, "Offences against the Person", in Chapter VI with the marginal name "Offences against Individual Freedom", we find the legal basis, Article 205, for the criminal offence with the marginal name "Illegal Deprivation of Freedom". Following the analysis of the legal text, we find that the offence has a simple form provided for in paragraph 1, an assimilated form provided for in paragraph 2 (abduction (kidnapping) of an individual in the case of the circumstantiated passive subject being a person either unable to defend himself/herself, or unable to express his/her will), and two aggravated forms, in paragraph 3, and respectively paragraph 4 . We also note that the punishment provided by the law is emprisonment, with a special minimum special of one year, and a special maximum of 15 years, for the aggravated form provided for in par. 4, if the consequence is the victim's death. Considering that the crime has both a typical form and an assimilated one, it is sufficient that it be committed in any of the forms. The deed will also exist if the deprivation of freedom only occurred for a short time, however, it remains a continuing offence, which leads us to consider there are two significant moments, that of consummation, and that of exhaustion.

\subsection{Regulation in the Criminal Code of Hungary}

In Chapter XVIII, bearing the marginal name "Offences regarding Personal Freedom", Section 194 comprises the legal content of the criminal offence of "Violation of Personal Freedom". In the basic form provided for in paragraph 1, subjects are not circumstantiated (do not form the object of any aggravating or mitigating circumstances), and in the aggravated form provided for in paragraph 2 , the following circumstantiations are present:

- as regards the active subject, he/she is armed with a weapon either within the meaning of letter $e$ ) when the active subject displays a deadly weapon, or within the meaning of letter $f$ ) when the active subject carries a deadly weapon. In the case of letter $h$ ), the qualification concerns "the unlawful impersonation of an

\footnotetext{
1 "Deprivation of freedom in any way means the activity that would result in depriving a person of the freedom to move freely for a while."
} 
Debreceni Jogi Múhely 2021. (XVIII.) 3-4.

Debreceni Egyetem, Állam- és Jogtudományi Kar, Debrecen

(University of Debrecen, Faculty of Law, Debrecen)

DOI 10.24169/DJM/2021/3-4/2

authority". In a similar manner, in the Romanian Criminal Code, in Art. 205 with the marginal name "Illegal Deprivation of Freedom", in the aggravated form mentioned in paragraph 3, letter a), the active subject is an armed person ${ }^{2}$, within the meaning indicated in Article 179, paragraph 1, or the assimilated meaning, as presented in paragraph 2 .

- in reference to the passive subject, we note that he/she is also circumstantiated (the object of circumstances) in the case of letter $a$ ), by the capacity of underaged (minor) person, and in the case of letter d), by being perpetrated against a person incapable of self-defence. In a similar manner, in the Romanian Criminal Code, in Art. 205, in the aggravated form indicated in paragraph 3, letter b, the passive subject is a minor. The deed will be classified as a criminal offence in the aggravated form if the perpetrator's motives are malicious, and malice aforethought is retained (letter b), as well as in the case of aggravating circumstances, such as: causing physical harm (letter $c$ ), or if significant harm to the interests has been caused (letter $g$ ).

In the same chapter, but as a distinct criminal offence with the marginal name Kidnapping, in Section 190, the special criminal rule of the Hungarian Criminal Code criminalizes the deed of the person who deprives another person of his/her personal freedom. The forms of the offence also result from the six paragraphs. Thus, in paragraph 3, letter $c$ ), the kidnapping that results in the death of the victim is criminalized as an aggravated form. In a similar manner, in the Romanian Criminal Code, in Art. 205, with the marginal name "Illegal Deprivation of Freedom", provides, as an aggravated form, in paragraph 3, the deed committed with oblique (exceeded) intent, if it resulted in the victim's death. We also highlight, in terms of the legal content, in paragraph 1 , letter $b$ ), the assimilated form as being the kidnapping of a person who is defenceless or unable to express his will. ${ }^{3}$

\subsection{Regulation in the Criminal Code of the Republic of Italy}

In Part III bearing the marginal name "On Misdemeanours against Individual Freedom", among the five sections ${ }^{4}$, we find, in section II, Article 605, with the marginal name "Forcible Confinement of Persons". We note that the offence has a simple form, as provided for in paragraph 1, three aggravated forms provided for in paragraphs 2 to 4 and a mitigated form, provided for in paragraph 5.

While in the simple form provided for in paragraph 1, subjects of the offence are not circumstantiated, in the aggravated form mentioned in paragraph 2 , we find mutually circumstantiated subjects, in the situation shown in point 1 (when the damage is suffered by an an ascendant, a descendant or a spouse), and a circumstantiated active subject in the situation shown in point 2 , when the deed is committed by a public official. From the aggravated form provided for in paragraph 3, sentence 1, it results that the active subject is circumstantiated by the capacity of minor, and in sentence 2 , the legislator provides for essential requirements either with regard to the minor, such as: a 14-year old minor, or with regard to the circumstances under which the deed is committed so as to harm the minor (the circumstances are those indicated in paragraph 2 or when the minor is forcibly confined or detained abroad). In the same context, for a passive circumstantiated subject, paragraph 4 provides the deed committed with oblique intent when a more serious outcome has occurred, namely the death of the minor. The special impunity cause is provided for in paragraph 5 , when the penalties provided for in paragraph 3 are reduced by half if, as a result of the investigations carried out or during the investigations, it results that the defendant either did his best to free the minor, or "helps the police or the court when gathering evidence". The defendant's cooperation will be retained as a special mitigating circumstance in view of identifying or catching the perpetrators and, also, if the defendant, through the help provided, contributes to the reconstruction of the facts or to the avoidance of the commission of new deeds that can be classified as forcible confimenment of a minor. By comparing the punishments, we note that the Italian legislator provided a penalty of no less than 6 months

\footnotetext{
2 Article 179 of the Romanian Criminal Code shows what the meaning of a weapon is.

${ }^{3}$ For law enforcement issues related to public safety, see: Madai, 2020a, pp. 188-194. and Madai, 2020b, pp. 49-53.

${ }^{4}$ In each section, social values such as the following are protected: individual freedom, personal freedom, mental freedom, inviolability of domicile.

${ }^{5}$ Article 605 of the Criminal Code of the Republic of Italy.
} 
Debreceni Jogi Múhely 2021. (XVIII.) 3-4.

Debreceni Egyetem, Állam- és Jogtudományi Kar, Debrecen

(University of Debrecen, Faculty of Law, Debrecen)

DOI 10.24169/DJM/2021/3-4/2

and no more than 8 years of imprisonment for the typical form, no less than 1 year and no more than 10 years of imprisonment for the first aggravated form, and no less than 3 years and no more than 12 years of imprisonment for the second aggravated form, sentence 1, or no less than 3 years and no more than 15 years of imprisonment for the deed indicated in sentence 2. The Italian special criminal rule provides for the penalty of life imprisonment if the outcome of the deed was the minor's death.

\subsection{Regulation in the Criminal Code of Greece}

Chapter XVIII bears the marginal name "Offences against Personal Freedom" and comprises Articles 322 to 335. We are highlighting Article 325, with the marginal name "Illegal Deprivation of Freedom". The material element of the objective side can be achieved either through deprivation of freedom or through any kind of restrictions to the freedom of movement. There are some essential requirements in relation to the objective side, namely: the deprivation of freedom should "occur against the will" of the passive subject. The criminal offence is in a continuing form, in the case indicated in sentence 2, from which the aggravated form results, if the passive subject is illegally deprived of freedom for "a long period of time". The subjects of the crime are not circumstantiated, they can be any person. In the same chapter, in Article 326, we find the legal basis for the offence bearing the marginal name "Unconstitutional Deprivation of Freedom" in cases where a person "violates one of the provisions of Article 6 of the Constitution". With reference to kidnapping (abduction), which in the Romanian regulation is the assimilated form of the offence provided for in Article 205 of the Criminal Code, we note that in the Criminal Code of Greece there are three articles criminalizing illegal deprivation of freedom, with different marginal names, specifically: Abduction of Minors (Article 324), Involuntary Kidnapping (Article 327) and Elopement (Voluntary Kidnapping) (Article 328). In the case of these offences, the subjects are circumstantiated as follows:

- In Article 324, the passive subject is circumstantiated by the capacity of minor (in paragraph 1 ) and by that of a minor under the age of 14 years (in paragraph 2). We note that the Criminal Code of Greece has expressly regulated in the legal contentthe situation of the minor under 14 years of age, by retaining the typical form indicated in paragraph 1, in cases where the deed is committed "by a relative in the ascending line";

- In Article 327, by retaining the typical form indicated in Article 325, the passive subject is circumstantiated, as it can only be a woman, with the essential requirement that the deed should be committed without her willing it. If the woman is intellectually deficient or is unable to resist, the fulfillment of the purpose expressly provided for in the legal content will make the difference between retaining the simple form or the aggravated form. In cases where the purpose is marriage, the offence will be in the mitigated form, and in cases where the purpose is to have promiscuous relations, it will be in the aggravated form;

- In Article 328, the active subject is circumstantiated as being a "single, minor" woman. Also, the purpose will make the difference between retaining the simple form or the aggravated form, being similar to Article 327. However, in the case of this Article, we retain the essential requirement that the deed should be committed with the woman's consent, but "without the consent of the legal representatives or of the persons in whose care she has been entrusted". As regards the punishments provided by the law, we retain that, in the case of the criminal offence of illegal deprivation of freedom, for the typical form, the penalty is imprisonment without specification of its duration (in which case it will be correlated with Art. 53 of the Criminal Code of Greece, the maximum penalty being five years, and the minimum penalty, ten days), and in the case of the aggravated form, imprisonment for at least one year is provided, without specification of the maximum limit. For unconstitutional deprivation of freedom, the penalty provided by the law is at least six months, without indication of the special maximum penalty.

\section{Guaranteeing the right to education through online schooling}

In the context of the pandemic extension, the global catastrophe showed its consequences over the course of two years. Many countries imposed, at the outset of the pandemic, restrictions and lockdown protocols and strict measures for the management of the Covid-19 pandemic. Educational entities transferred their activities online, in Romania, as well as in many other countries. As a result, educational units resorted to 
Debreceni Jogi Múhely 2021. (XVIII.) 3-4.

Debreceni Egyetem, Állam- és Jogtudományi Kar, Debrecen

(University of Debrecen, Faculty of Law, Debrecen)

DOI 10.24169/DJM/2021/3-4/2

online courses and to the mediation of web platforms dedicated to education. Of course, this led to social effects, but also to effects in terms of online communication, given that it is very different from face-toface communication. The provision of high-quality education is largely dependent on the competencies and approach of the teaching staff, who require appropriate motivation to offer the educational efficiency expected by society. The position of educational managers and teachers cannot be minimized, considering that education is one of the fundamental conditions underlying the development of any society and any country (Getange, 2016, pp. 33-38).

The study of the modes in which educational systems make use of online communication is constantly developing, along with unprecedented technological developments and with the need for organizations to communicate effectively. Information technology, as well as the widespread use of online applications, now puts us in a position where the online communication process offers opportunities to ensure the right to education. Obviously, this effort is guaranteed by specialists in computer programming and science, and facilitates the use of tools by communicators without technical training. Technologies are becoming accessible in terms of knowledge, many of them are free of charge and can be adapted to the needs of organizations that want to develop online communication. On the one hand, we refer to online communication tools that have to do with communication with target groups (social media profiles, company blog, official website), and on the other hand, we refer to tools that facilitate communication between members for the purpose of effective collaborative work, such as the use of Google Docs and Google Drive on a large scale or of platforms of the Moodle type (Hosu et al., 2019, p. 20).

When teachers communicate with students, either in a face-to-face class or an online class, they communicate inorder to provide knowledge or to receive information in order to acquire understanding and development within the framework of institutional relations.

Communication with students in an online environment involves more effort and planning as compared to communication in a physical, traditional environment, because in the online environment body language is absent. Teachers have the advantage of using body language and facial expression in a face-to-face class to draw the students' attention and convey the message to them. When interacting in an online class, teachers cannot use body language to help their students to communicate. Being aware of the limitations of online communication can help them decide how to establish adequate communication in a timely manner and how to interact effectively with students online. All these actions and methods of providing educational services reflect the intention of the institutional system to provide students with access to education and vocational training. Media education also involves the ability to access the information media, to understand and critically evaluate various aspects thereof and their content, as well as to create communication in a wide variety of contexts. In the current information society, media education is linked to social inclusion and to belonging to a system through citizenship. It is a fundamental competence not only for young people, but also for adults and the elderly, parents, teachers and professionals in the field of education or that of massmedia.

Thanks to the Internet and information technologies, an increasing number of citizens can create and broadcast images, information and content. The responsibility for determining how to include them in school curricula at all levels lies primarily with the states, which guarantee freedoms and access to education. The role played by local authorities is also very important, as they are closer to citizens and support initiatives in terms of the various forms and methods of providing educational services.

\section{Online learning and face-to-face learning}

Digital technology has facilitated on a large scale the continuation of distance teaching activities during periods of suspension of classes. However, some of the usual (face-to-face) teaching activities cannot be carried out online/remotely, thus having a negative impact on learning and developing skills. Teachers report dysfunctions with regard to the following learning support activities: genuine communication and establishing human connection, personalized support for students with special learning needs, interaction with average students (Botnariuc et al., 2020, p. 4).

The Criminal Code of Romania, in Title VIII, bearing the marginal name "Offences That Harm Social 
Debreceni Jogi Múhely 2021. (XVIII.) 3-4.

Debreceni Egyetem, Állam- és Jogtudományi Kar, Debrecen

(University of Debrecen, Faculty of Law, Debrecen)

DOI 10.24169/DJM/2021/3-4/2

Relationships", in Chapter II with the marginal name "Offences against Family", Art. 380, criminalizes the deed of preventing access to compulsory general education. Thus, the offence with the aforementioned marginal name is presented, in paragraph 1 , in the typical form. The active subject is circumstantiated, as he/she can be only the parent or person to whom the minor was entrusted. The passive subject is circumstantiated, the legal content providing for his/her capacity, that of minor (juvenile).

The material element can be achieved through the first alternative method of withdrawing the minor from classes, with the essential requirement that they should belong to compulsory general education, or by preventing him/her from attending classes. The legislator provides for essential requirements related to the material element, namely that the active subject should act without justification and, in the case of the access prevention method, this should be retained regardless of the means used by the perpetrator.

Paragraph 2 provides for an impunity cause which is applicable until the end of the criminal prosecution. The essential requirement that must be met is related to the defendant, in the sense that he must ensure the resumption of school attendance by the minor.

Paragraph 3 provides for two exceptions, as follows: in sentence 1, the situation in which the criminal action may be extinguished (referred to in Art. 17, Romanian Criminal Procedure Code, paragraph 2), namely: the court orders, where appropriate, the deferred enforcement of the penalty. Sentence 2 of the same paragraph also provides for the possibility of ordering the suspension of the enforcement of the penalty, even if the conditions provided by law are not met, but in any case, the essential requirement related to the active subject must be fulfilled, namely that he must ensure the resumption of school attendance by the minor. The defendant's behaviour must be changed by the time at which the conviction judgment becomes final.

First of all, most authors define "online learning" as access to learning experiences through the use of certain technologies. Other researchers, such as Benson (2002, pp. 443-452) and Conrad (2002, pp. 1-19), define online learning as being a rather modern form of distance learning that improves access for students by identifying educational opportunities for learners described as both non-traditional and disenfranchised. Many researchers discuss not only the use of online learning, but also its connectivity, mobility and interactivity in terms of ensuring access to educational services. The development of the Internet and information technology has persuaded educational systems in many countries to adapt their courses in ways that allow them to use technology. This change has been influenced by a number of factors, including meeting the needs of a university and school student population, dealing with the financial pressures placed on institutions (e.g., pressure to educate more with fewer resources), and ensuring that students have the technological skills that are increasingly expected of the workforce. In addition, most educational systems want to be at the forefront of many areas of practice, including the use of information technology.

In the last ten years, evaluations of teaching courses by using the Internet have increased significantly, mainly as a result of a greater focus on the quality of teaching and the need for accountability with regard to the educational act (Duța and Pănisoara, 2015, p. 45). This focus on high-quality teaching has led to a formative assessment in view of improving the teaching and learning process (e.g. classroom assessment techniques, intermediate assessment, focus on groups of students who use technical means with internet connection).

The emphasis on educational accountability has also led to summative evaluation for promotion purposes, teaching awards, additional funding decisions, all seen in the light of regulations that ensure students' access to educational services even if they take place online, not in the public spaces intended for activities that are part of the educational process.

Researchers such as Hiltz and Turoff (2005, pp. 64-73) make it clear that online learning is a modern form of distance learning or an updated version of the manner in which education is provided. Like many other researchers, these authors believe that there is an interdependence between distance education or distance learning and online learning.

Among the difficulties encountered in carrying out distance teaching activities, teachers point out the following: the lack of tools for class management, feedback and assessment, technical difficulties - platforms that need to be installed, that do not work, or work poorly. Other difficulties are: the lack of teaching materials for conducting sufficiently efficient and/or attractive learning activities for all students, the lack of suitable tools for teaching-learning-assessment in certain subjects, the lack of educational content (digital 
Debreceni Jogi Múhely 2021. (XVIII.) 3-4.

Debreceni Egyetem, Állam- és Jogtudományi Kar, Debrecen

(University of Debrecen, Faculty of Law, Debrecen)

DOI 10.24169/DJM/2021/3-4/2

resources) in the subject concerned, the lack of high-performance terminals (computers and tablets) and the lack of time to understand and use digital tools and resources appropriately (Botnariuc, 2020, p. 12).

\section{Conclusions}

We have tried to provide an overview of the research regarding online educational methods, and especially the integration of digital media into education, which excludes accusations of freedom restrictions or of the lack of access to education. The transfer of teaching methods allowed the identification of many fields of study that were developed in different periods and under different epistemologies, methodological and didactic assumptions that were put into practice with certain difficulties.

Despite all these technological limitations, we can asseert that major efforts have been made by most countries to ensure access to education and ongoing training without the obligation of home confinement being considered a restriction of rights or, even worse, a deprivation of freedom. We believe that our analysis explains the accusations expressed by citizens in the public domain with regard to these limitations and it is necessary to create strategies for a more effective communication in the institutional and public sphere.

The criminal codes of countries provide for the criminal offence of illegal deprivation of freedom, but the hypothesis that lockdown (quarantine), restriction of access to the public domain, confinement of persons and online education include all the constituent elements of the crime in its typical form cannot stand. We highlight the lack of intention as a form of guilt, which is necessary for the legal classification of the deed as a criminal offence.

\section{Bibliography:}

The Romanian Constitution of 31 $1^{\text {st }}$ October 2003 published in the Official Journal. Part I, no. 677 of $31^{\text {st }}$ October 2003, amended and supplemented by the Law on the revision of the Romanian Constitution no. 429/2003, published in the Official Journal. Part I, no. 758 of 29th October 2003.

Law no. 286/2009 on the Criminal Code, published in the Official Journal no. 510 of 24th July 2009

Antonowicz, L., Soobrayan, P., Shabani, N. (2020). Crearea unor sisteme de educatie reziliente in contextul pandemiei de COVID-19 (Creating Resilient Educational Systems in the Context of the COVID-19 Pandemic). UNICEF Regional Office for Europe and Central Asia, Geneva, Switzerland, available online at: https://www.unicef.org/romania/media/2836/file.

Benson, A.D. (2002), "Using online learning to meet workforce demand: a case study of stakeholder influence", Quarterly Review of Distance Education, Vol. 3 No. 4.

Botnariuc, P., Cuco, C., Glava, C., Iancu, D., Ilie. M, Istrate, O., Labăr, A.V., Pânișoară, I.O., Ștefănescu, D., Velea, S. (2020), Școala online (Online School), Editura Universităţii din București (Bucharest University Publishing House), Bucharest.

Brun, J.P. (2010), Missing Pieces: 7 Ways to Improve Employee Well-Being and Organizational Effectiveness, Palgrave Macmillan, New York, NY.

Cheney, G. (2011), Organizational Communication in an Age of Globalization: Issues, Reflections, Practices, Waveland Press, Long Grove, IL.

Conrad, D. (2002), "Deep in the hearts of learners: insights into the nature of online community", The Journal of Distance Education, Vol. 17 No. 1.

Dongoroz Vintilă, „Explicații teoretice asupra Codului Penal român” (Theoretical Explanations regarding the Romanian Criminal Code), vol. III, Edit. Academiei (Academy Publishing House), Bucharest, 1969.

Duta, N., Panisoara, G. and Panisoara, I.O. (2015), The Effective Communication in Teaching. Diagnostic study regarding the academic learning motivation to students, Procedia-Social and Behavioral Sciences, Vol. 186. https://doi.org/10.1016/j.sbspro.2015.04.064 
Debreceni Jogi Múhely 2021. (XVIII.) 3-4.

Debreceni Egyetem, Állam- és Jogtudományi Kar, Debrecen

(University of Debrecen, Faculty of Law, Debrecen)

DOI 10.24169/DJM/2021/3-4/2

Getange, K.N. (2016), Motivational strategies and teachers' productivity: lessons of experience from public secondary schools in Kisii county, Kenya, IOSR Journal of Research and Method in Education, Vol. 6 No. 4.

Glomo-Narzoles, D.T. (2012), Communication climate: its relation to institutional productivity, Asian Journal of Social Sciences and Humanities, Vol. 1 No. 4.

Hilliard, A.T. and Newsome, E. Jr (2013), Effective communication and creating professional learning communities is a valuable practice for superintendents", Contemporary Issues In Education Research, Vol. 6 No. 4. https://doi.org/10.19030/cier.v6i4.8102

Hiltz, S.R. and Turoff, M. (2005), "Education goes digital: the evolution of online learning and the revolution in higher education", Communications of the ACM, Vol. 48 No. 10, pp. 59-64. eting Research, Vol. 16 No. 1. https://doi.org/10.1145/1089107.1089139

Hosu, I., Culic, D., Deac, M. (2019), Comunicarea online (Online Communication), Revista Transilvană de Ştiințe Administrative (Transylvanian Review of Administrative Sciences) 2(35)/2014.

Hung, M.L., Chou, C., Chen, C.H. and Own, Z.Y. (2010), "Learner readiness for online learning: scale development and student perceptions", Computers and Education, Vol. 55 No. 3. https://doi.org/10.1016/j.compedu.2010.05.004

Jurik, V., Groschner, A. and Seidel, T. (2014), "Predicting students' cognitive learning activity and intrinsic learning motivation: how powerful are teacher statements, student profiles, and gender?", Learning and Individual Differences, Vol. 32. https://doi.org/10.1016/j.lindif.2014.01.005

Keyton, J. (2011), Communication and Organizational Culture: A Key to Understanding Work Experience, Sage, Thousand Oaks, CA.

Lambrechts, W., Mul_a, I., Ceulemans, K., Molderez, I. and Gaeremynck, V. (2013), “The integration of competences for sustainable development in higher education: an analysis of bachelor programs in management", Journal of Cleaner Production, Vol. 48. https://doi.org/10.1016/j.jclepro.2011.12.034

Madai, S. (2020a), Aspecte ale securității persoanei și ale comunității in societatea magbiară din punctul de vedere al ordinii publice - abordare teoretică, In: Iancu, Elena-Ana (ed.) Siguranța persoanei şi construirea capitalului social: Arad, 2019. november 8. Bucuresti, Universul Juridic SRL., pp. 188-194.

Madai, S. (2020b), Some thoughts on performing a law enforcement public task as a public service, Agora International Journal of Juridical Sciences, No. 2. pp. 49-53.

Moore, J.L., Dickson-Deane, C. and Galyen, K. (2011), e-Learning, online learning, and distance learning environments: are they the same? The Internet and Higher Education, Vol. 14 No. 2. https://doi.org/10.1016/j.iheduc.2010.10.001

Okello, P.G. (2015), The Effect of Human Resource Practices on Students' Performance at St. John Bosco Core Primary Teachers, Uganda Management Institute, College Nyondo, Uganda, Doctoral dissertation.

Orodho, J.A., Waweru, P.N., Ndichu, M. and Nthinguri, R. (2013), Basic education in Kenya: focus on strategies applied to cope with school-based challenges inbibiting effective implementation of curriculum, International Journal of Education and Research, Vol. 1 No. 11.

Shan, S., Li, C., Shi, J., Wang, L. and Cai, H. (2014), "Impact of effective communication, achievement sharing and positive classroom environments on learning performance", Systems Research and Behavioral Science, Vol. 31 No. 3. https://doi.org/10.1002/sres.2285

Summers, D.C. (2010), Quality Management: Creating and Sustaining Organizational Effectiveness, Prentice Hall, Upper Saddle River, NJ.

Taleb Nassim Nicholas, Lebăda neagra: impactul foarte puțin probabilului (The Black Swan: The Impact of the Highly Improbable), $2^{\text {nd }}$ edition, revised and added, translated from English by Viorel Zaicu, Bucharest, 2010.

Vasili T., Pavel D., Antoniu G., D. Lucinescu, V. Papadopol, V. Rămureanu, „Codul penal comentat şi adnotat” (Commented and Annotated Criminal Code), Vol. I, Bucharest, 1975, p.165 
Debreceni Jogi Múhely 2021. (XVIII.) 3-4.

Debreceni Egyetem, Állam- és Jogtudományi Kar, Debrecen

(University of Debrecen, Faculty of Law, Debrecen)

DOI 10.24169/DJM/2021/3-4/2

Velentzas, J.O.H.N. and Broni, G. (2014), "Communication cycle: definition, process, models and examples”, Recent Advances in Financial Planning and Product Development, Proceedings of the 5th International Conference on Finance, Accounting and Law (ICFA '14), Istanbul, Turkey, 15-17 December 2014.

***Raportul privind accesul elevilor la educatia in mediul online (Report regarding the access of students to online education), 2020, https://consiliulelevilor.ro/wp-content/uploads/2020/04/Raport-privind-accesul-elevilor-laeduca $\%$ C $\%$ \% 9 Bie- $\%$ C3\%AEn-mediul-online.pdf 